\title{
Organizational infrastructure of innovation processes in Russian Russia
}

\author{
Elena Kuznetsova ${ }^{1, *}$, Elena Cherepanova ${ }^{1}$, and Alexey Gamberg ${ }^{1}$ \\ ${ }^{1}$ Mechanics and Machine Building Institute, Ural Federal University, Russia
}

\begin{abstract}
The study presents the regional and national statistics, allowing drawing the conclusions about the state of the innovation process, its elements, and their relationships. The main result of the study is the identified "gap" between basic science as the object of creating innovations and manufacturing enterprises as the object of the implementation of innovations. According to the authors, there is a necessity for the process control for not only the creation, but the implementation of innovations in production; the formation of an infrastructure that can provide the interaction of science and industry, the transformation of scientific developments into the manufacturing process now. This structure should be a buffer zone between the elements of the innovation process, create an area of mutually beneficial cooperation. The article considers the evolution of scientific development transformation in production. The organizational model of "innovation-to-production" transfer established on the small innovative enterprises affiliated with the leading educational institutions is suggested. The merits and drawbacks of the organizational interaction models in the "higher education institution-the small innovative enterprise-the enterprise" chain are shown.
\end{abstract}

\section{Introduction}

The mutual integration of science and business is one of the most pressing problems of the Russian economy associated with the accumulation of the innovative capacity of the country. The vector of the government intervention in this sector was visible most distinctly in the last 3 years. In particular, when the Federal law № 217-FZ "On Amendments to Certain Legislative Acts of the Russian Federation on the Establishment of Budget Scientific and Educational Institutions' Business Entities for the Purposes of Practical Application (Implementation) of Intellectual Activities" was enacted, it directly united the scientific capacity of higher education institutions and business by the allocation of the particular business type - the small innovative enterprises with the special conditions of governmental support, focused on a specific activity kind, which functioning mechanism is described in the article by Lugovtsov, Gamberg [1]. Lately a large number of commercial structures of this type were opened to solve the problem of the diffusion of innovations described by Rogers [2]. Nevertheless, the increase in number of such companies makes it more and more obvious that the existing infrastructure, created to simplify the work process of the subjects in this sphere, does not meet the requirements. The small innovative enterprises, created at higher education institutions, should be granted the commercialization functions. Now various funds support development, but, obviously, the time has come to pay special attention to the implementation financing, which is defined in the Federal law and described in the research by Yershova and.Kopytov [3].

The objective of the research, which results are given in the article, is the identification of the problem elements in the industrial enterprises innovative development process, discussion of innovation degree assessment indicators and the proposition of the ways to increase the innovations introduction process efficiency [4].

\section{Assessment of innovate development level}

In modern scientific practice a number of indicators are applied to the assessment of the enterprise innovative activity: the "integrated indicator of innovative activity" introduced by Opekun. [5], "Russian index of the innovative level of the enterprises", "functional dependence of the competitiveness level and innovations", etc. used by Mutanov and Esengaliyeva [6]. The international ratings, for example, the Global Innovation Index (in 2014 rating of the Russian Federation was 39,$1 ; 49$ place) $[7,8]$ are applied to estimate the innovative activity of the country. These ratings are used for the comparative analysis between the countries based on the level of competitiveness. This method was proposed by Atkinson and. Ezell [9]. The options of estimation based on the level of competitiveness are "competitiveness through cooperation" indicators, suggested by . Teixeira [10]

\footnotetext{
Corresponding author: eltcha@mail.ru
} 
and "sustainable development" used by Hay and others, Vollebergh, Kemfert, and White in their researches [1113]. Some researchers, for example Cooke or Buyanova consider the region as a significant unit of consideration in the question of innovation ensuring because the innovative clusters are mostly created at the regional level, the region creates local legislative and infrastructure conditions to provide innovation for the enterprises [14-16], but there are approaches, for example by Hamel . or Kuznetsova which suggest that the development of innovation comes "from the bottom up: the enterprises form competitiveness of the region" [17,18]. As Trifonov and Veretennikova note, that there are no unified index, criteria, or unified approach to the estimation of complex indicators for the innovative activity of regions evaluation. [19]. Just like in case with the country, the assessment of the regional innovative activity is suitable for the comparative assessment. The comparative assessment can be used for the same object in dynamics (for identification of the innovative development trends), and for comparison of the different objects. It is expedient for investors to use the results of such comparative assessment to choose the object of investment.

The known indicators of the innovation level (for the enterprise, region and country) are integrated, and it is difficult to isolate the influencing factors. The integrated indicators do not give the chance to define ways of further development and innovative development efficiency of the research object - the enterprise.

\section{Russian practice of innovative development}

The Russian practice of the economy innovation assessment level is the following. According to the State Committee of Statistics, expenses on researches and development within the country were about $1 \%$ of GDP in 2012. This level is preserved for the last several years (Figure 1). There is a need for the estimation of the innovative activity financing level and science as the source of innovations, from the point of view of its efficiency and sufficiency. Figure 1 shows the expenses on science funding from the GDP in dynamics since 2000.

For example, Aganbegyan suggests that investments in production innovations become innovative result in 35 years [21]. Fig. 1 shows dynamics of a number of the used advanced production technologies across the Russian Federation on some mechanical engineering subindustries. In the view of the any economic system development efficiency, the fundamental industries, implementing innovative products and technologies should be manufacturing industries, including mechanical engineering as one of the progress engines because of its position at the beginning of the technological chain of the technological chain of any production.

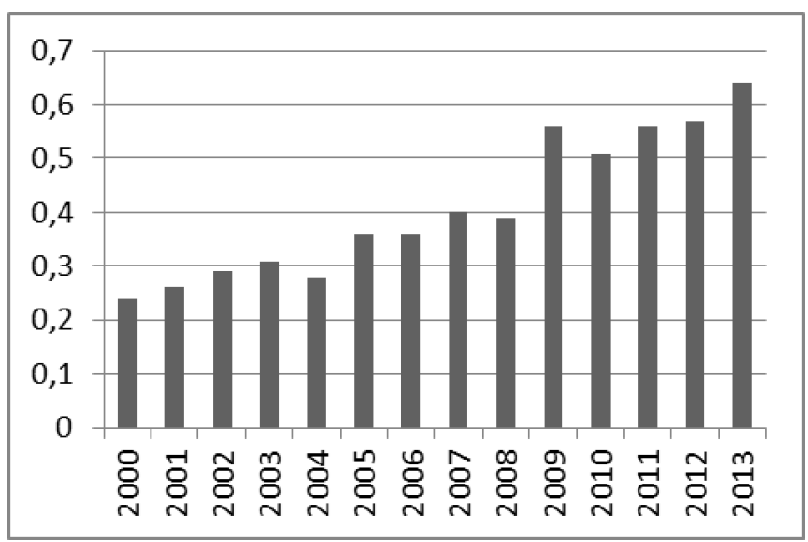

Fig. 1. Financing of the scientific development dynamics (\% of GDP) - the State Committee of Statistics [20].

The chart shows that the level of innovative introduction decreases with the growth of the scientific developments financing (Fig. 2) and the need for them increase. This situation can only be estimated as a negative tendency because only the introduced innovative technologies can be considered as successful and as the instrument of the innovative development of the industry in general.

\section{Problem of innovative development}

Blinkov and Mogilenskikh describe the practical problem of the innovative development in the Russian industry as the "gap" between the efforts made by the government to intensify the innovative development and the reached results. [22] One of the episodes proving the mentioned problem existence is the following. Five years ago the Ural Federal University created innovative structure (a belt of innovative enterprises) to provide the Ural industrial enterprises with innovative products and to stimulate the update of the product line. The analysis of the statistical data showed that in 2012 more than 60 small innovative enterprises were created within the innovative structure of UrFU [23].

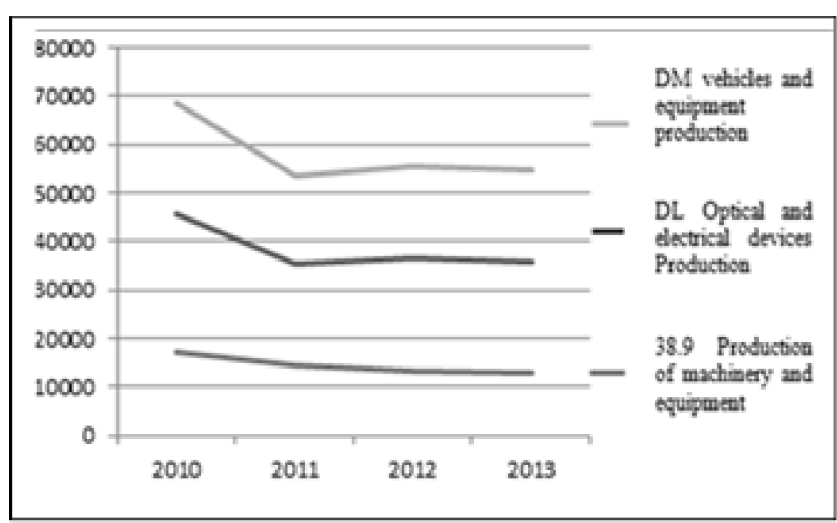

Fig 2. Number of the used advanced production technologies in Russian Federation on some subindustries (units) [20].

At this moment there are more than 80 enterprises, but there is no intensive growth of the innovative industry in Yekaterinburg, or in the Ural region. The 
created innovative enterprises did not give the multiplicative effect of the innovative production volume growth.

Considering the diverse structure of economy of the Russian Federation, it is possible to assume, that not all regions are equally interested in the introduction of the innovations, for example, some agrarian regions can distort the general statistics by its indicators. Let us consider the main results of Ural Federal District enterprises' activity in 2012 as one of the industrial regions of the country (Table 1$)[4,20]$.

Table 1. The main results of the Ural Federal District enterprises' activity in 2012 [4, 20].

\begin{tabular}{|c|c|}
\hline Index & $\begin{array}{l}\text { Data on Ural Federal } \\
\text { District, rating among } \\
\text { sub-federal units of the } \\
\text { Russian Federation, value }\end{array}$ \\
\hline $\begin{array}{l}\text { By the total index of the local } \\
\text { production goods shipped volume, by } \\
\text { the types of economic activity, } \\
\text { "manufacturing activities", place, } \\
\text { million rubles. }\end{array}$ & $\begin{array}{l}\text { 4th } \\
3211212\end{array}$ \\
\hline $\begin{array}{l}\text { By the index of industrial production, } \\
\text { place, } \%\end{array}$ & $\begin{array}{l}\text { 8th } \\
101.3\end{array}$ \\
\hline $\begin{array}{l}\text { By the index of industrial production } \\
\text { by the types of economic activity } \\
\text { "manufacturing activities", place, } \%\end{array}$ & $\begin{array}{l}2 \text { nd } \\
107.9\end{array}$ \\
\hline $\begin{array}{l}\text { The number of the organizations, } \\
\text { engaged in the scientific development, } \\
\text { place, units }\end{array}$ & $\begin{array}{l}5 \text { th } \\
236 \text { (3566-countrywide) }\end{array}$ \\
\hline $\begin{array}{l}\text { The number of the personnel engaged } \\
\text { in the scientific researches, place, } \\
\text { number of people }\end{array}$ & $\begin{array}{l}\text { 5th } \\
43879(726318 \\
\text { countrywide }) \\
\end{array}$ \\
\hline $\begin{array}{l}\text { Self-financing of the basic researches, } \\
\text { place, million rubles. }\end{array}$ & $\begin{array}{ll}\text { th } \\
3832.6 \\
\end{array}$ \\
\hline $\begin{array}{l}\text { Self-financing of the applied } \\
\text { researches, place, million rubles. }\end{array}$ & $\begin{array}{l}7 \text { th } \\
3084.5\end{array}$ \\
\hline Patent applications, place, units & $\begin{array}{l}7 \text { th } \\
2326 \text { (42180 countrywide) }\end{array}$ \\
\hline Given out patents, place, units & $\begin{array}{l}\text { th } \\
1994 \text { (33633 countrywide) }\end{array}$ \\
\hline Level of inventive activity, place & $8^{\text {th }}$ \\
\hline $\begin{array}{l}\text { Volume of the innovative goods, } \\
\text { works, services, place, million rubles. }\end{array}$ & $\begin{array}{l}5 \text { th } \\
148696.2(2872905.1 \\
\text { countrywide) }\end{array}$ \\
\hline $\begin{array}{l}\text { Proportion of the innovative goods, } \\
\text { works, services in total production, } \\
\text { place, } \% \text {. }\end{array}$ & $\begin{array}{l}8 \text { th } \\
2.1 \text { ( } 8 \text { countrywide })\end{array}$ \\
\hline
\end{tabular}

It should be noted that URFO is the smallest industrial region, as on the population (6th place), and on the area. Despite the modest size, rather small amount of the population, the region possesses enormous experience of industrial development and scientific support of production, caused by historical, natural and resource aspects. All this allows the region to reach good results: for example, now, the 2nd place on the level of industrial production. In spite of the rather high level of industrial production output and industrial production index, the level of innovative activity in the region is insufficient, and on the innovative production, works and services implementation volume, URFO is on the last positions in comparison with other regions. Other researchers of the problem also came to the similar conclusions, e.g. Ruban or Baev and Drozin [24,25]. At the same time, URFO industrial complex and areas within, for example, the Sverdlovsk region is one of the largest in the country. But this complex was created a long time ago and initially served for the military purposes. In the modern conditions the survival of such industrial region as URFO demands increase of enterprises and productions competitiveness, which only depends on the success of the existing branches and productions innovative updates. It should be noted that URFO has the smallest difference between submitted patent applications and the given patents that proves the quality of scientists and schools of sciences in the region. At the available industrial development requirements, including the level of the industrial production, share of the industrial output, at the regional level we see lack of created, introduced and expertly confirmed innovations implementation.

Thus, it is necessary to look for the reasons which led to the low level of implementation of innovative development, technologies, and products. Over the past few years the financing level did not change essentially, and the number of enterprises which are engaged in the scientific development did not change either. According to the Federal State Statistics Service, the level of inventive activity (coefficient of inventive activity and the number of the domestic patent applications for inventions submitted in Russia per 10 thousand people of the population) essentially did not change for the last 3 years and makes 2 units. Thus, we cannot speak about decrease in inventive level or number of inventions, but the lack of the worked out system of the scientific researches implementation in production is obvious.

So, the lack of the innovations adaptation mechanism in the existing productions is proved. Obviously, there is a gap between the efforts made by the state government and the regional authorities, and the results in the industry which should be expressed in the realized innovative production volumes.

\section{Organizational infrastructure}

The innovative activity of the region and state should be shown in the conditions creation for the innovations implementation by the enterprises, i.e. in the creation of policy in the field of innovative development, support, and priorities which, as a result, develop into the regulation of the innovative production market, ensure the stability of demand, and the tax regime allowing the enterprise to allocate the earned funds for the development, in other words the creation of innovative processes organizational infrastructure [4].

Figure 3 shows the logic of the innovation assessment in the enterprise (the left column) and innovation of the region (the right column), and the necessary system of their interrelation (infrastructure for innovations).

We analysed the schematic diagram of interaction between the scientific and innovative enterprises and real production, existing in the Soviet period (Figure 4).

The manufacturing enterprise will not be, and should not be engaged in any form of the basic scientific researches. Industry-specific scientific research institutes in the USSR took on both applied and exploratory 
research that allowed receiving a finished innovation for the industrial enterprise. After the total closing of the scientific research institutes at the beginning of the 1990s, many enterprises had to stop the innovations implementation completely or independently conduct both applied and exploratory researches. The budget for the research had to be found by the enterprise. Without innovations the product quickly loses the client (decrease in quality, consumer properties, etc.), and researches demand essential financial investments from the enterprise.

Now allocation in the budget of the enterprise for the scientific research and experimental-design development (the Soviet term), or on R\&D - researches and development (modern term) is expedient. With these funds the enterprise can buy the innovations in the market and implement them in production; or the enterprise can "order" development for its needs.

In world practice science and technology parks carry out the function of the buffer between the fundamental science and manufacturing enterprises.

The small enterprises working in the science and technology parks are engaged, generally in commercialization of the scientific developments, making a commercial product, and then realizing this product.

There are cases when the major companies buy the innovation together with the company-developer. But the Russian experience of the science and technology parks successful functioning of is low, the majority of the created technology parks remain the formal organization which does not carry out its main function commercialization, introduction, and development.

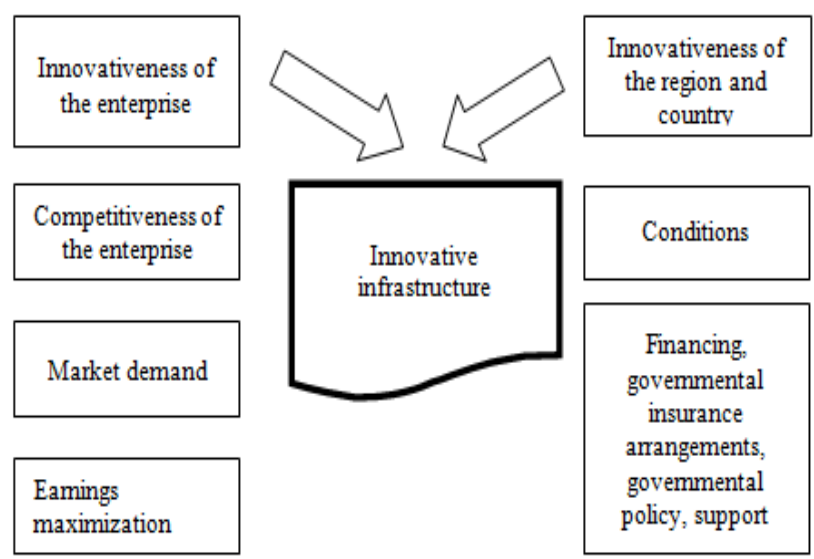

Fig. 3. Infrastructure of the innovative process.

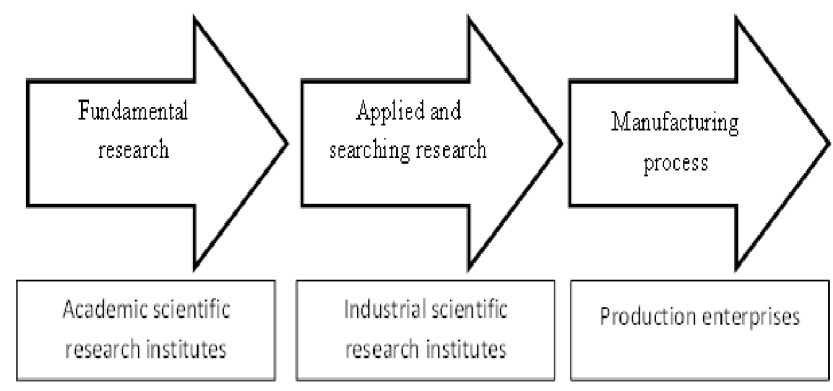

Fig. 4. Research and production realization system of the research results.
The reduced taxation for the science parks land is the reason for this. The results of the science park activity were not controlled, often in the "science and technology park" banal and even handicraft production took place, and the innovative developments were not carried out, as described in the researches by Krivorotov,. Kuznetsova $[3,26,27]$. In the foreign practice companies have to pass a competition to get into the science park, and time of their presence in the park is limited to the time of the project implementation. At the moment it is necessary to speak about the creation of organizational infrastructure for the transfer of the basic research results to production. Federal law № 217 defines the small innovative enterprise (SIE) activity - practical application (implementation) of the intellectual activity results. Thus, SIEs should replace the disappeared scientific research institutes and ineffective science and technology parks.

We conducted a study of existence and structure of the economic, organizational and scientific and technical barriers in the domestic market of innovations. During the research the heads of the small innovative enterprises created at the leading higher education institutions of Yekaterinburg, Chelyabinsk and Novosibirsk were interviewed. The enterprises founded with the assistance of the Ural Federal University, the Southern Ural State University and Novosibirsk State University were used in the selection [1].

The directors were proposed to list barriers that interfere with the development of their enterprises on the current stage of activity and, which, in their opinion, they may face further. During the interview the respondent was asked to rank the offered types of barriers on extent of their influence on the company activities on a scale from 0 to 3 points, where 0 is no influence, 3 is a very high influence.

The received results were processed by the method of averaging observations, mode and medians among the indicators given by the respondents to each of the barriers. On the basis of these calculations, several diagrams were constructed (Figures 5, 6, 7). The charts show the weight of each estimated barrier during all stages of the small innovative enterprise life cycle [1], according to the director (Figure 6).

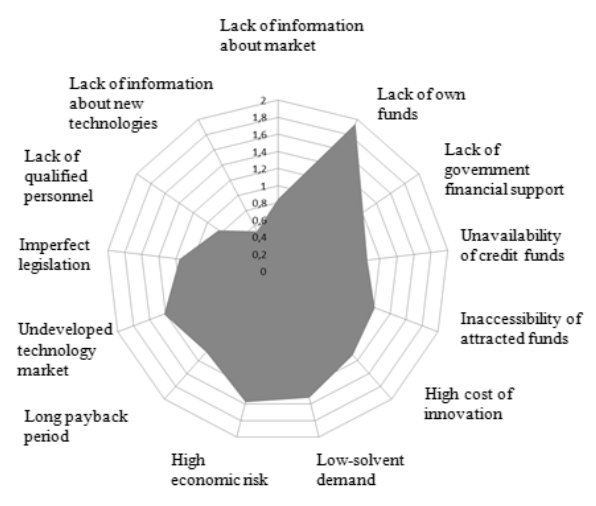

Fig. 5. Average index according to barriers evaluation by the businessmen. 


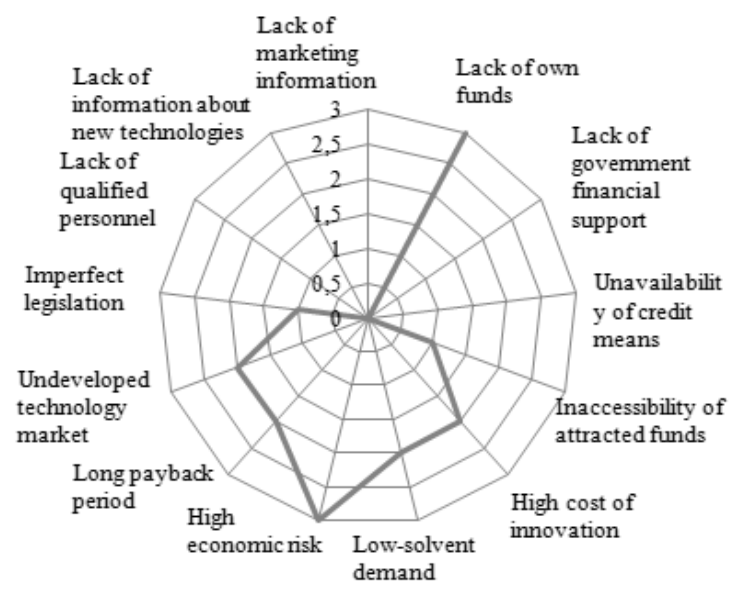

Fig. 6. Size of the mode barriers assessment by the businessmen.

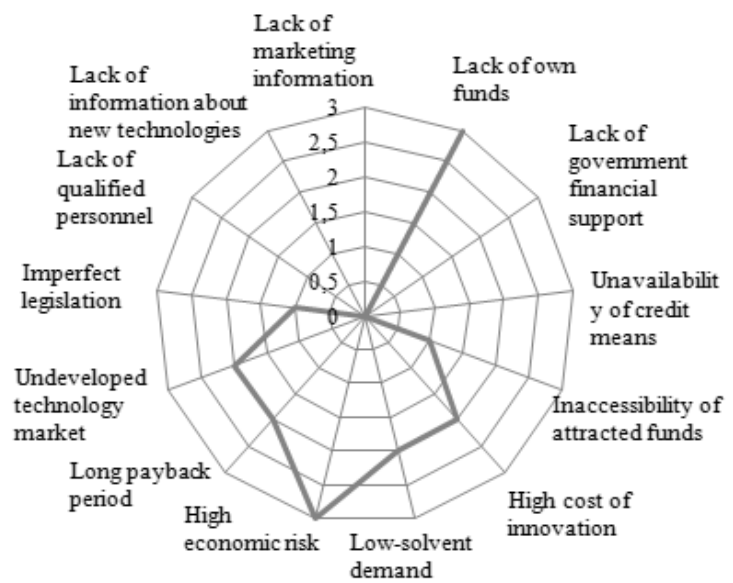

Fig. 7. Size of the median barriers assessment by the businessmen.

At the moment there are several players in the market promoting breaking of the barriers on the way of innovations implementation (Table 2).

Table 2. Classification of the innovative infrastructure elements which promote overcoming of the barriers.

\begin{tabular}{|c|c|c|}
\hline Characteristic & Classification & Example \\
\hline \multirow[t]{3}{*}{$\begin{array}{l}\text { Size of a } \\
\text { property } \\
\text { complex }\end{array}$} & $\begin{array}{l}\text { Single } \\
\text { organizations }\end{array}$ & $\begin{array}{l}\text { Industrial enterprises, funds, } \\
\text { investment companies, business } \\
\text { angels, banks, etc. }\end{array}$ \\
\hline & Associations & $\begin{array}{l}\text { Science and technology parks, } \\
\text { scientific clusters, venture funds, } \\
\text { etc. }\end{array}$ \\
\hline & $\begin{array}{l}\text { Special } \\
\text { technology } \\
\text { development } \\
\text { zones }\end{array}$ & $\begin{array}{l}\text { Innovative and implementation } \\
\text { centers (Skolkovo) }\end{array}$ \\
\hline \multirow{3}{*}{$\begin{array}{l}\text { Purposes and } \\
\text { nature of } \\
\text { activity }\end{array}$} & Commercial & $\begin{array}{l}\text { Banks, production platforms, } \\
\text { etc. }\end{array}$ \\
\hline & $\begin{array}{l}\text { Non } \\
\text { commercial }\end{array}$ & Support funds, state programs \\
\hline & Mixed & $\begin{array}{l}\text { Data-processing centers, science } \\
\text { and technology parks, clusters, } \\
\text { etc. }\end{array}$ \\
\hline \multirow[t]{2}{*}{$\begin{array}{l}\text { Technology of } \\
\text { support }\end{array}$} & Indirect & $\begin{array}{l}\text { Through privileges, subsidies, } \\
\text { subintermediary services }\end{array}$ \\
\hline & Direct & Through purchase of a share, \\
\hline
\end{tabular}

\begin{tabular}{|c|c|c|}
\hline & & $\begin{array}{l}\text { direct investments, services of } \\
\text { production }\end{array}$ \\
\hline \multirow[t]{4}{*}{ Activity } & Financial & $\begin{array}{l}\text { Venture funds; banks, business } \\
\text { angels; private investment } \\
\text { companies; }\end{array}$ \\
\hline & $\begin{array}{l}\text { Research and } \\
\text { production }\end{array}$ & $\begin{array}{l}\text { Production platforms, research } \\
\text { and production clusters, higher } \\
\text { education institutions, } \\
\text { exchanges of innovations }\end{array}$ \\
\hline & Legal & Consulting companies \\
\hline & Complex & $\begin{array}{l}\text { Science and technology parks, } \\
\text { data-processing center, business } \\
\text { incubators }\end{array}$ \\
\hline \multirow[t]{3}{*}{ Used resource } & Private & $\begin{array}{l}\text { Private investor, venture, } \\
\text { commercial enterprises }\end{array}$ \\
\hline & State & Funds, unitary enterprises \\
\hline & Mixed & Government corporations \\
\hline \multirow{2}{*}{$\begin{array}{l}\text { Capital } \\
\text { accessory }\end{array}$} & National & \multirow{2}{*}{$\begin{array}{l}\text { Foreign venture funds, business } \\
\text { incubators and production } \\
\text { platforms }\end{array}$} \\
\hline & Foreign & \\
\hline
\end{tabular}

Table 3. Elements of the innovative infrastructure usage for the barriers orercome.

\begin{tabular}{|c|c|c|}
\hline Barrier & $\begin{array}{l}\text { Infrastructure } \\
\text { element }\end{array}$ & Overcoming mechanism \\
\hline $\begin{array}{l}\text { Lack of own } \\
\text { funds }\end{array}$ & $\begin{array}{l}\text { Banks, funds of } \\
\text { support }\end{array}$ & $\begin{array}{l}\text { Attraction and loan of funds } \\
\text { from the state and commercial } \\
\text { sources }\end{array}$ \\
\hline $\begin{array}{l}\text { High } \\
\text { economic } \\
\text { risk }\end{array}$ & $\begin{array}{l}\text { Business angels, } \\
\text { venture funds }\end{array}$ & $\begin{array}{l}\text { Division of implementation risks } \\
\text { with strategic and portfolio } \\
\text { investors }\end{array}$ \\
\hline $\begin{array}{l}\text { High cost of } \\
\text { innovations }\end{array}$ & $\begin{array}{l}\text { Science and } \\
\text { technology park, } \\
\text { business incubator }\end{array}$ & $\begin{array}{l}\text { Reduction of the product costs } \\
\text { by cooperation with other } \\
\text { companies in the science and } \\
\text { technology parks, decrease in } \\
\text { constant expenses due to the } \\
\text { usage of the business incubators } \\
\text { resources }\end{array}$ \\
\hline
\end{tabular}

Generalizing the above-mentioned and relying on the foreign and domestic experience, the usage of the small innovative enterprises created at higher education institutions and scientific institutions as the engine for innovative process in Russia is possible only on the condition of the necessary infrastructure creation meaning availability of the accurately fulfilled mechanism of overcoming scientific and technical, organizational and economic barriers.

\section{Conclusions}

We suggest putting into practice such mechanism by forming the organizational infrastructure elements, which are available in the market in a continuous overcoming barriers chain where the innovation moves from its appearance in the form of small innovative enterprise to the issue on a big market.

\section{References}

1. A.V. Lugovtsov, A.E. Gamberg, Proc. of the IVth int. conf., 217-225 (2014)

2. E.M. Rogers, Diffusion of Innovations (Free Press, New York, 1983)

3. I.V. Yershova, I.V. Kopytov, Questions of management, 11, 48-53 (1985) 
4. E.Y. Kuznetsova, O.O. Podolyak, P.V. Mezentsev, URFU Messenger. Series economy and management, 1, 96-113 (2015)

5. E.V. Opekun, G.A. Hatskevich, Theoretical and applied questions of economy, 23, 96-105 (2011)

6. G.M. Mutanov, Zh.S. Esengaliyeva, Basic researches, 3(3), 712-717 (2012)

7. The Global Innovation Index - global research and the rating of the countries of the world accompanying it on an indicator of development of innovations according to the international business school (INSEAD). http://gtmarket.ru/ratings/globalinnovation-index/info

8. The Global Innovation Index 2014 The Human Factor in Innovation. http://www.globalinnovationindex.org/content.aspx? page $=$ gii-full-report-2014

9. R.D. Atkinson, S.J. Ezell, Innovation Economics.The Race for Global Advantage (Yale University Press, New Haven, 2012)

10. A.A. Teixeira, Cambridge Journal of Economics, 38, 181-214 (2014)

11. L. Hay, A. Duffy, R.I. Whitefield, Journal of Environmental Management, 13(3), 232-257 (2014)

12. H.R.J. Vollebergh, C. Kemfert, Ecological Economics, 54, 133-147 (2005)

13. M.A. White, Ecological Economics, 86, 213-217 (2013)

14. Ph. Cooke, Geoforum, 23, 365-382 (1992)

15. Ph. Cooke, Industrial and Corporate Change, 10, 945-974 (2001)

16. M.E. Buyanova, L.V. Dmitriyev, Bulletin of the Volgograd state university, 2, 54-62 (2012)

17. G. Hamel, Harvard Business Review, 87, 91-98 (2009)

18. E.Y. Kuznetsova, E.A. Chopovda, URFU Messenger, Economy and management Series, 2, 27-35 (2013)

19. Yu.V. Trifonov, A.A. Veretennikova, The Bulletin of the Nizhny Novgorod university of N.I. Lobachevsky, 6(1), 244-284 (2013)

20. Federal State Statistics Service. http://www.gks.ru/

21. A.G. Aganbegyan, Forecasting problems, 4, 3-16 (2014)

22. M.O. Blinkov, O.P. Mogilensky, Problem of economy and management, 3, 32-34 (2010)

23. Innovative infrastructure of the Ural Federal University. http://www.inno.urfu.ru/

24. D.A. Ruban, Messenger URFU, 78-96 (2015).

25. I.A. Bayev, D.A. Drozin, Messenger URFU, Economy and management series, 2, 97-110 (2015)

26. E.Y. Kuznetsova, The Organizer of production, 1, 37-43 (2011)

27. V.V. Krivorotov, A.V. Kalina, E.A. Tikhanov, S.E. Erypalov, Messenger URFU, Economy and management series, 2, 61-74 (2014) 